一論 文—

（日本化学会誌，1990，（7)，p.753～758)

(C) 1990 The Chemical Society of Japan

\title{
凍結乾燥法による $\mathrm{Pb}\left(\mathbf{Z r}_{x}, \mathbf{T i}_{1-x}\right) \mathbf{O}_{3}$ の合成
}

\author{
（1990 年 4 月 2 日 受理）
}

近 藤 知 ${ }^{* *} \cdot$ 掛 川一幸・佐々木義典

チタン, ジルコニウム，鉛の混合硝酸塩溶液の凍結乾燥により $\mathrm{Pb}(\mathrm{Zr}, \mathrm{Ti}) \mathrm{O}_{3}(\mathrm{PZT})$ を合成した（全 凍結乾燥法)。またチタン, ジルコニウムの混合硝酸塩溶液の凍結乾燥生成物を熱分解したものと $\mathrm{PbO}$ との固体間反応によっても PZT を合成した（組み合わせ法）。これらの合成法，および一般に行われ ている固相法について反応性，均一性などを比較検討した。

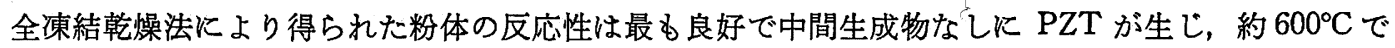
単一相の PZT が得られた。組み合わせ法でも中間生成物は生じず， 単一相の PZT は $900^{\circ} \mathrm{C} て ゙$ 得ら

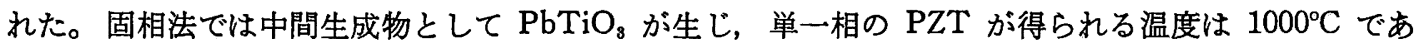
った。

固相法により合成された PZT には大きな組成変動（組成不均一性）が認められた。全凍結乾燥法と 組み合わせ法により合成された PZT の組成変動は検出精度内では認められなかった。

誘電率の温度特性を調べた結果, 全凍結乾燥法および組み合わせ法を用いて得られた PZT の誘電率 の最大値はともに，乾式法による PZT の 2 倍程度の值をもっていた。

\section{1 藉言}

$\mathrm{PbZrO}_{3}-\mathrm{PbTiO}_{3}$ 系固溶体（以下 $\mathrm{PZT}$ と略記する）懮れた 王電性を示し，王電材料として広く用いられている。PZTは一 般には $\mathrm{PbO}$ と $\mathrm{TiO}_{2}, \mathrm{ZrO}_{2}$ の固体間反応により合成される（乾 式法)。この方法により合成された PZT には大きな組成変動（組 成の不均一性）が生じることがすでて示されている122。組成変動 が存在するとCurie 温度付近での誘電率のピークが幅広くなる。 また PZT では $X=0.535$ のモルホトロピック相境界（以下 MPB と略記する) の組成で瓦電係数がピークを示すが, 組成変 動が存在すればこのピークが広がってしまい，MPB での優れた 特性を十分引き出すことはできなくなる。

一般に組成变動を小さくするためには液相から原料粉体を調製 する湿式法による合成が有効である。液相から原料粉体を得る方 法としては（1）溶液の $\mathrm{pH}$ 調整，（2）アルコキシドの加水分 解，（3）貲䨳熱分解法，（4）凍絬乾燥法などがあげられる。著 者らはこれまでにこれらの方法により得られた PZT の組成変動

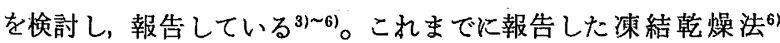
は，チタンとジルコニウムの混合硝酸塩溶液を凍結乾燥後, 熱分

千葉大学工学部応用化学科, 260 千葉市弥生町

** 現在 東ソ一株式会社, 252 綾瀬市早川

1）掛川一幸, 边潔, 毛利純一, 山村 博, 白㥓信一, 日 化, 1976, 413 .

2）掛川一幸, 毛利純一, 高橋䊏一郎, 山村 博, 白崎信一, 日化, 1976, 717 .

3) K. Kakegawa, J. Mohri, J. Am. Ceram. Soc., 68, C-204(1985).

4）掛川一幸, 毛利純一, 今井蜸, 白崎信一, 高橋紘一郎, 日化, 1985,692 .
解して得られた混合酸化物と $\mathrm{PbO}$ との固体間反応により PZT を合成するものである（凍結乾燥一畭式組み合わせ法, 以下組み 合わせ法と略記する)。この方法は固溶体の同一の格子位直には いる成分のみを湿式法で得て，これと残りの成分と固体間反応さ せる湿式一畭式組み合わせ法を利用したものである。湿式一乾式組

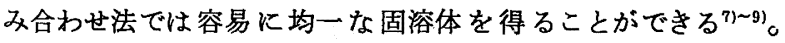
PZT を涷結乾燥法により合成する場合, 湿式一乾式組み合わせ法 を用いると合成の際の時間的な効率の点から有利である。

PZT の構成陽イオンすべてを含む溶液の涷結乾燥では, 組み 合わせ法より反応性の高い PZT の原料粉体が得られる可能性が ある。本報告では, チタン, ジルニウム, 鉛の混合硝酸塩溶液 の涷結乾燥 (全涷結乾燥法) による PZT の合成を試み, 組み合 わせ法および乾式法を含め総合的に生成過程, 組成変動, 電気的 特性などの検討を行った。

\section{2 実験}

\section{1 試料の調製}

(a) 乾式法

$\mathrm{PbO}, \mathrm{ZrO}_{2}, \mathrm{TiO}_{2}$ を所定のモル比で科量し, めのう乳鉢で十 分混合後, 約 $75 \mathrm{MPa}$ で直径䄪 $13 \mathrm{~mm}$ 厚さ約 $1 \mathrm{~mm}$ の圧粉体

5) K. Kakegawa, K. Arai, Y.Sasaki, T. Tomizawa, J. Am. Ceram. Soc., 71, C-49(1988).

6）近藤 知, 掛川一幸, 佐々木義典, 電化, 58, 87(1990).

7) K. Kakegawa, J. Mohri, S. Shirasaki, K. Takahashi, J. Am. Ceram. Soc., 67, C-2(1984).

8）掛川一幸, 毛利純一, 白崎信一, 山村 博, 高橋粧一郎, 日化, 1974, 10.

9) S. Shirasaki, K. Takahashi, K. Kakegawa, J. Am. Ceram. Soc., 56, 430(1973). 
にプレス成型した。この圧粉体を閉じられたマグネシア二重るつ ほ ${ }^{101}$ にいれ， $1100^{\circ} \mathrm{C}$ で 1 時間炷結させた。この際 $\mathrm{PbO}$ の蒸発を 防止するため, $\mathrm{PbO}$ と $\mathrm{ZrO}_{2}$ の等モル混合物 $\left(\mathrm{POZ}^{111}\right)$ を同封し た。

\section{（b）全凍結乾燥法}

図 1 に全凍結乾燥法による PZT の合成手順を示す。まず四塩 化チタン水溶液、二塩化酸化ジルコニウム水溶液をそれぞれ所定 の割合で混合した。全凍結乾燥法では $\mathrm{Pb}^{2+}$ を含む溶液を調製する 必要があるが，この四塩化チタンと二塩化酸化ジルコニウムの混 合水溶液は塩化物イオンを含むため $\mathrm{Pb}^{2+}$ を溶かすことがでさな い。そこで混合溶液を次の手順により硝酸塩の形に変えた。混合 溶夜を約 $6 \mathrm{M}$ のアンモニア水中に滴下して水酸化物沈殿を得た。 この沈殿を蒸留水で洗浄した後, 濃硝酸に溶解した。この溶液の 正確な濃度を重量分析により求め, 溶液に含まれるチタンとジル

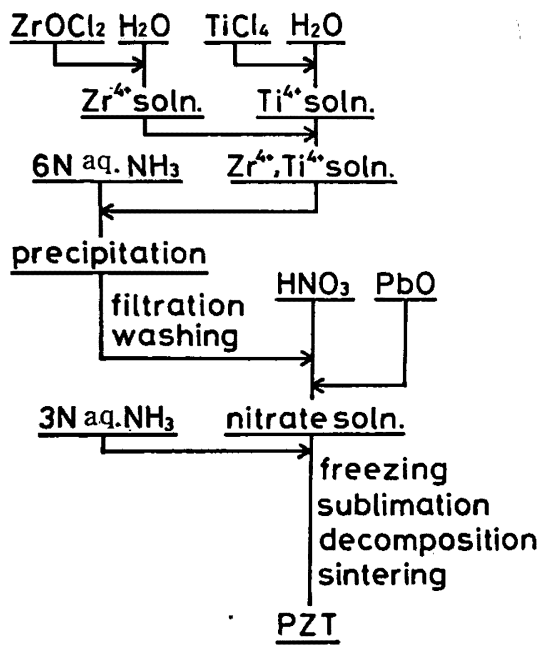

Fig. 1 Process for the preparation of PZT by a freeze drying of a mixed solution of titanium nitrate, zirconium nitrate and lead nitrate (FULL method).

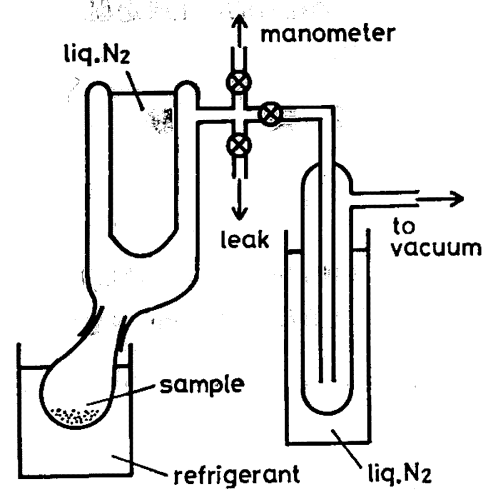

Fig. 2 Apparatus used for the freeze drying

10）特川一幸, 邦男, 佐々木羲典, セラミックス論文誌 96, 681(1988).

11）岡绮 清, 案協, 66, 74(1958).
コニウムと同モルの $\mathrm{PbO}$ をこれに溶解させた。この溶液に希ア ンモニア水を加え $\mathrm{pH}$ の調整を行った。 $\mathrm{pH}$ 条件の検討から硝酸 塩溶液の $\mathrm{pH}$ が 1.8 未満の場合, 引き続いて行ら昇華乾燥中に 凍結粒子の融解が起こることがわかった。そのため溶液の $\mathrm{pH}$ は 1.8 以上にする必要があった。この溶液をかきまぜた液体窒素中 に毛管を通して貲出させ涷結粒子を生成させた。得られた凍結粒 子をなす形フラスコに入れ，図 2 のよらな装置で約 $10^{-3} \mathrm{mmHg}$ の減正下で昇華乾燥を行った。この際凍結粒子の融修を防ぐため なす形フラスコの周囲を寒剤 (水 $+\mathrm{NaCl})$ によ $-5^{\circ} \mathrm{C}$ に保っ た。

乾燥終了後試料を取りだすと潮解性を示した。そのため昇華乾 燥終了後, 引続き減正下でなす形フラスコの周囲をマントルヒー ターにより $120 \sim 130^{\circ} \mathrm{C}$ に昇温させ熱分解を行った。この処理を 行った試料は潮解性を示さなかった。そこでこの処理を行った 後, 試料を凍結乾燥装置から取り出し,さらに $550^{\circ} \mathrm{C}$ で熱分解し て酸化物とした。そして得られた酸化物を, 乾式法の場合と同様 に焼結させた。

\section{（c） 組み合わせ法}

図 3 亿組み合わせ法による PZT の合成手順を示す。まず全凍 結乾燥法と同様にしてチタンとジルコニウムの混合硝酸塩溶液の 調製を行った。この溶液の $\mathrm{pH}$ を希アンモニア水により 1.8 に 調整し，全凍結乾燥法之同様な方法で涷結乾燥，減圧下での熱分 解を行った。そして得られた生成物を $650^{\circ} \mathrm{C}$ て熱分解して酸化物 とした。得られた酸化物（以下 FD-ZT と略記する）に必要量の $\mathrm{PbO}$ を加えめのう乳鉢で混合後, 乾式法と同様に焼結させた。

\section{$2.2 \mathrm{X}$ 線回折}

粉末 X 線回折測定は理学電機製の粉末 X線回折装 置 (RAD-B システム）を用いた。X線源は銅とした。定性用光学系は発散ス リット $(\mathrm{DS})=1^{\circ}$, 受光スリット $(\mathrm{RS})=0.3 \mathrm{~mm}$, 散乱スリット $(\mathrm{SS})=1^{\circ}$ とし，モノクロメーターを用いて $K_{a}$ 特性 X線により

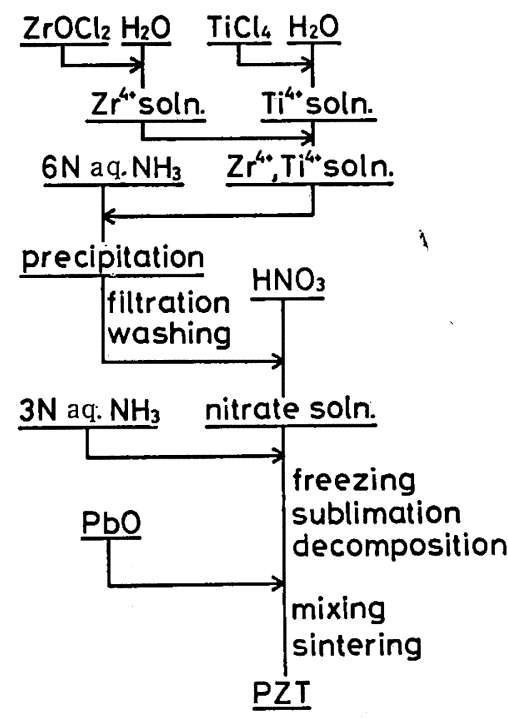

Fig. 3 Process for the preparation of PZT by solidsolid reaction between $\mathrm{PbO}$ and a mixed oxide prepared by a freeze drying of a mixed solution of titanium nitrate and zirconium nitrate (COMBINATION method). 
測定した。半価幅の測定時にはモノクロメーターをはずし受光ス リットを $0.15 \mathrm{~mm}$ とし、ニッヶルフィルターを用いて測定した。 $\mathrm{X}$ 線回折ピークを最小二乗法により，次式を使って一致させた。

$$
I(2 \theta)=\frac{A}{1+B(2 \theta-C)^{2}}+\frac{0.5 A}{1+B(2 \theta-C-\Delta)^{2}}
$$

ここで $I(2 \theta)$ は，回折角 $2 \theta$ での回折強度からバックグラウ ンドを差し引いた值， $A, B, C$ は定数， $\Delta$ は回折角 $2 \theta$ での $\mathrm{Cu} K_{\alpha 1}, K_{\alpha 2}$ 二重線の回折角の差である。この一致により，試料 の単一波長 X線に対する回折ピークの半価幅が求められる。ケイ 素の単一波長に対する半価幅 $b$ を求め, $2 \theta \sim b$ との関係をプロッ トした。このbの值を X線回折装置の分解能による広がりとみな した。PZT 試料についても，同様の一致により単一波長に対する 半価幅を求め, $2 \theta \sim b$ の関係からその回折角に拈ける $b$ の值を読 み取り試料の半価幅から差し引き，試料自体による回折ピークの 広がり $\beta$ とした。

乾式法，組み合わせ法および全凍結乾燥法での焼成時の相变化 は, 高温 X線回折装置（理学電機製）により追跡した。昇温速度 は $10^{\circ} \mathrm{C} / \mathrm{min}$ とし, $2 \theta=26^{\circ} \sim 35^{\circ}$ の間を往復走査し，その間に 現われるピークの変化を調べた。乾式法については, $2 \theta=26^{\circ}$ 〜 $35^{\circ}$ のピークだけでは相の判別が難しかったため, $2 \theta=43^{\circ} \sim 50^{\circ}$ の間む往復走査して追跡した。

\section{3 誘電率の測定}

ペレット状の焼結体の両面に銀ペースト（住友金属鉱山製 S8710）を塗布し， $500^{\circ} \mathrm{C}$ で 10 分間焼き付けた。この試料を電気 炬中にセットし温度を変え，LF インピーダンスアナライザー (YHP 4192 A 型) により電気容量を測定することにより誘電率 の温度特性を調べた。測定には $1 \mathrm{MHz}$ の周波数を用いた。

\section{3 結 果 と考察}

乾式法, 組み合わせ法および全凍結乾燥法での PZT の生成過 程を高温 X線回折により検討した。図 4 K $\mathrm{PbO}, \mathrm{ZrO}_{2}, \mathrm{TiO}_{2}$ の 混合物を $10^{\circ} \mathrm{C} / \mathrm{min}$ で昇温した時に存在した相の主要な回折ピー クの高さと温度との関係を示す。この過程は乾式法での反応過程 に相当する。 $600^{\circ} \mathrm{C}$ 付近から中間生成物の $\mathrm{PbTiO}_{3}$ が生成した。 この中間生成物は $800^{\circ} \mathrm{C}$ 付近から減少し始め, ほぼ同時に PZT が生成し始めた。単一相の PZT が得られるのは $1000^{\circ} \mathrm{C}$ 程度に なってからであった。 $\mathrm{PZT}$ の生成の前に $\mathrm{PbTiO}_{3}$ が生成する理 由はここで用いた $\mathrm{ZrO}_{2}$ の反応性が $\mathrm{TiO}_{2}$ の反応性に比較して低 いことによるものと考光られる。

図 5 は FD-ZT と PbO との混合物を昇温した時に存在した相 の主要な回折ピークの高さと温度の関係である。この過程は組み 合わせ法の反応過程に相当する。この方法では $550^{\circ} \mathrm{C}$ 付近で PZT が生成し始め, $900^{\circ} \mathrm{C}$ 付近で PZT の単一相となっている。 したがって組み合わせ法では，乾式法より $250^{\circ} \mathrm{C}$ も低い温度で PZT が生成し始めることになる。また中間生成物は生じなか った。これはチタンとジルコニウムのほとんどが反応性の高い $\mathrm{ZrTiO}_{4}$ を形成していることによるむのと考えられる。

図 6 はチタン, ジルコニウム，鉛の混合硝酸塩溶液の涷結乾燥 粉末を昇温した時の各相の主要な回折ピークの高さと温度との関 係である。この過程は全涷結乾燥法の反応過程に相当する。未㜔 成の凍結乾燥粉末は $\mathrm{Pb}\left(\mathrm{NO}_{3}\right)_{2}$ のピークのみを示した。チタンと

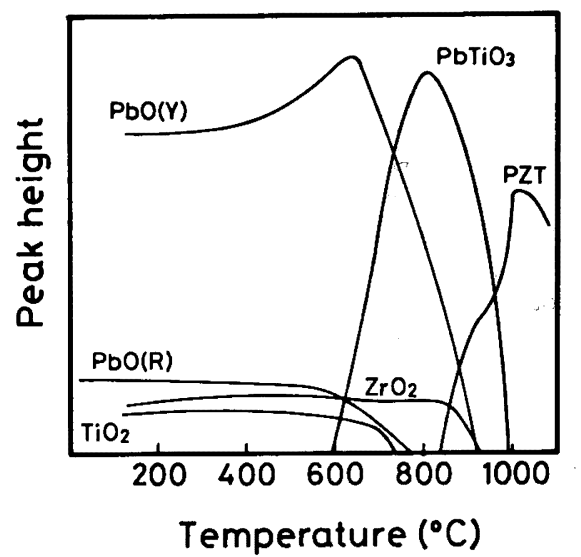

Fig. 4 Tracing of reaction process among $\mathrm{TiO}_{2}$, $\mathrm{ZrO}_{2}$ and $\mathrm{PbO}$

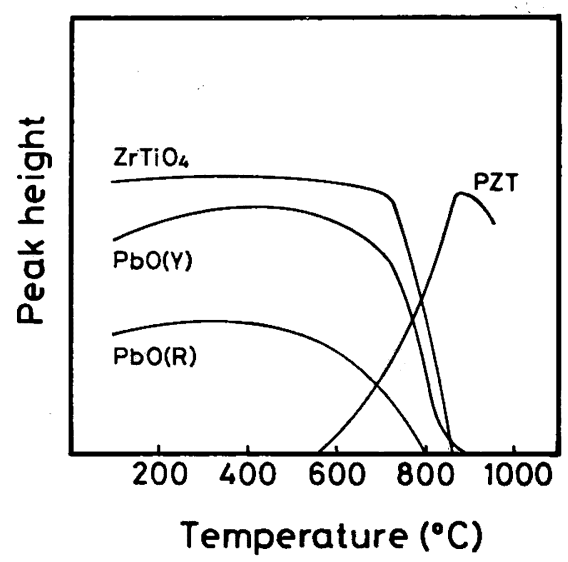

Fig. 5 Tracing of reaction process between $\mathrm{PbO}$ and a mixed oxide prepared by a freeze drying of a mixed solution of titanium nitrate and zirconium nitrate

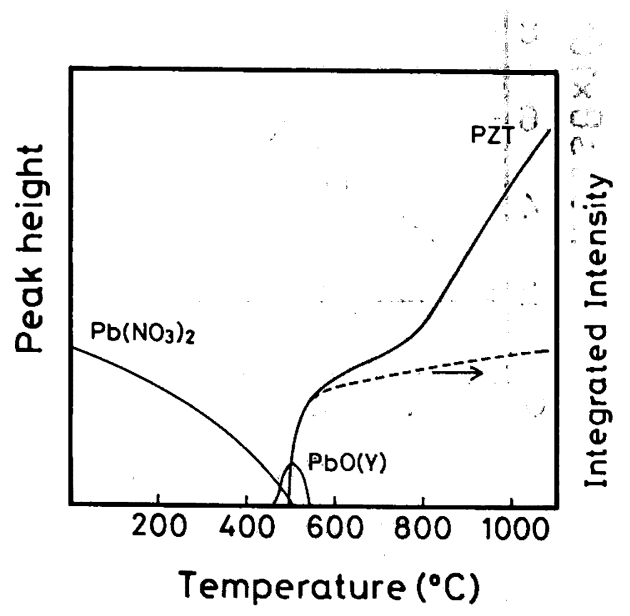

Fig. 6 Tracing of reaction process of the freeze dried prduct from a mixed solution of titanium, zirconium and lead nitrate 
ジルコニウム成分は非晶体になっているものと考えられる。この 方法でも中間生成物は現われず, $500^{\circ} \mathrm{C}$ 付近で PZT が生成し始 めている。罒中の破線は PZT のピークの面積強度と温度の関係 である。 $580^{\circ} \mathrm{C}$ 以上では面積強度の増加が小さいことがわかる。 よって $580^{\circ} \mathrm{C}$ 以の温度で PZT のピークの高さが高くなってい るのは, 結晶成長のためピークが鋭くなった結果と考えることが できる。したがって PZT の生成は $580^{\circ} \mathrm{C}$ 以下でほぼ完了してい ることがわかった。これはチタンとジルコニウム成分が非晶体と なっていて，反応性が高い状態にあることによるものと考えるこ とができる。全凍結乾燥法では, 乾式法より $300^{\circ} \mathrm{C}$, 組み合わせ 法より $50^{\circ} \mathrm{C}$ 低い温度で PZT が生成し始めることになる。これ らの方法の中では, 全凍結乾燥法が最も低温で PZT を合成する ことができる方法であることがわかる。

3 種類の方法により得られた PZT の組成変動を調べるため粉 末 X線回折による検討を行った。PZT において，c 軸の組成に対 する依存性は非常に小さいが，a 軸の長さは組成に対して顕著に 変化する。したがって組成変動は $\mathrm{a}$ 軸の長さの分布を生じさせる が, c 軸の長さには影響を与えない。このため組成変動のある試 料では $a$ 軸の長さのみによって回折角が決定される $h k 0$ 回折の ピークは幅広くなり， c 軸の長さのみによって回折角が決定され る $00 l$ 回折のピークは幅広くならない。回折ピークの広がりは 組成変動によるもののほかに, 結晶子が小さくなっても起こる。 この影響は $\beta \cos \theta \sim \sin \theta$ ( $\theta$ : 回折角) のプロットにより分離す ることができる。 $\beta \cos \theta \sim \sin \theta$ プロットは直線関係を示し，そ の勾配は格子面間隔の変動に一致する。 $k h 0$ 回折についてのプロ ットの勾配は $\mathrm{a}$ 軸の変動 $(\Delta a / a)$ であり, 組成変動の大きさに比 例する。

図 7 に乾式法により合成された $\mathrm{Pb}\left(\mathrm{Zr}_{0.3} \mathrm{Ti}_{0.7}\right) \mathrm{O}_{3}$ の $\beta \cos \theta \sim$ $\sin \theta$ プロットを示す。幹式法により得られた PZT では $h k 0$ 回 折についてのプロットに大きな傾きがみられ，大きな組成変動の あることがわかる。

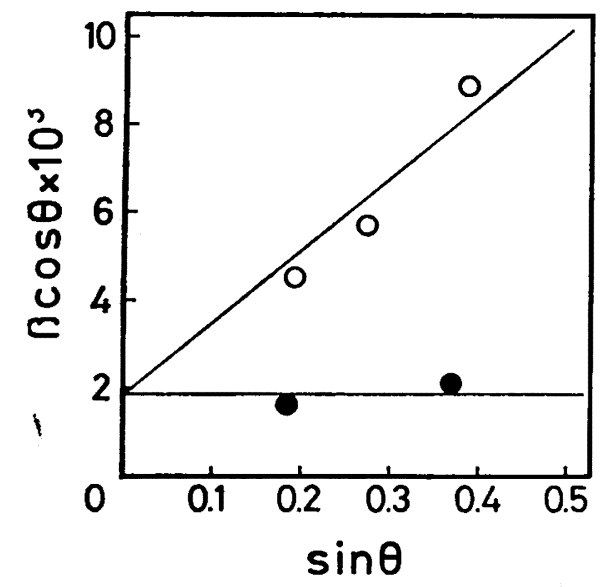

Fig. 7 Plots of $\beta \cos \theta$ vs. $\sin \theta$ for $\mathrm{Pb}\left(\mathrm{Zr}_{0.8} \mathrm{Ti}_{0.7}\right) \mathrm{O}_{3}$ prepared by a solid-solid reaction among $\mathrm{TiO}_{2}$, $\mathrm{ZrO}_{2}$ and $\mathrm{PbO}$

Firing conditions : $1100^{\circ} \mathrm{C}, 1 \mathrm{~h}$

$\mathrm{O}:$ For $h k 0$ diffraction,

: For $00 l$ diffraction
図 8 に全凍結乾燥法により合成された $\mathrm{Pb}\left(\mathrm{Zr}_{0.9} \mathrm{Ti}_{0.7}\right) \mathrm{O}_{3}$ の $\beta \cos \theta \sim \sin \theta$ プロットを示す。全凍結乾燥法による PZT では $h k 0$ 回折についてのプロットに勾配はみられず, この方法による 誤差の範囲内では組成変動は認められない。

凍結乾燥法と同様に溶媒と溶質とを分離する物理的な方法とし て噴蓩熱分解法がある。噴霧熱分解法の場合，鉛が高温で揮発し やすいため檏成陽イオンすべてを含む溶夜から品質のよいPZT

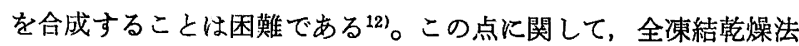
は低温で溶質と溶媒とを分離するため有利である。

図 9 に組み合わせ法により合成された $\mathrm{Pb}\left(\mathrm{Zr}_{0.3} \mathrm{Ti}_{0.7}\right) \mathrm{O}_{3}$ の $\beta$ $\cos \theta \sim \sin \theta$ プロットを示す。 $h k 0$ 回折についてのプロットに勾

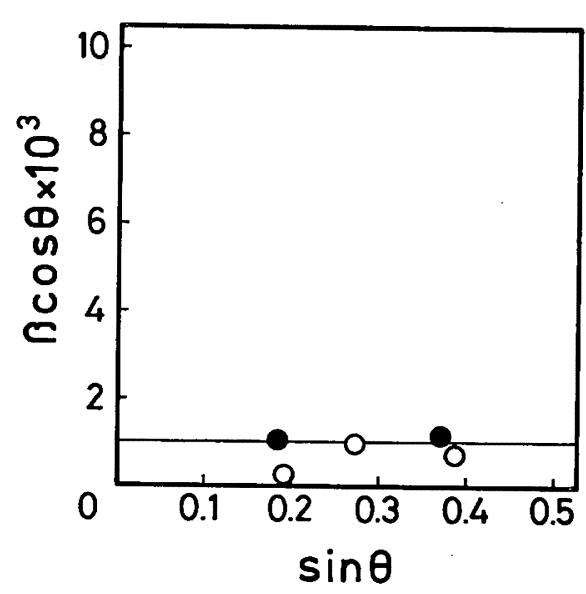

Fig. 8 Plots of $\beta \cos \theta$ vs. $\sin \theta$ for $\mathrm{Pb}\left(\mathrm{Zr}_{\mathrm{r}_{0.8}} \mathrm{Ti}_{0_{0.7}}\right) \mathrm{O}_{3}$ prepared by FULL method

Firing conditions : $1100^{\circ} \mathrm{C}, 1 \mathrm{~h}$

$\mathrm{O}:$ For $h k 0$ diffraction,

: For $00 l$ diffraction

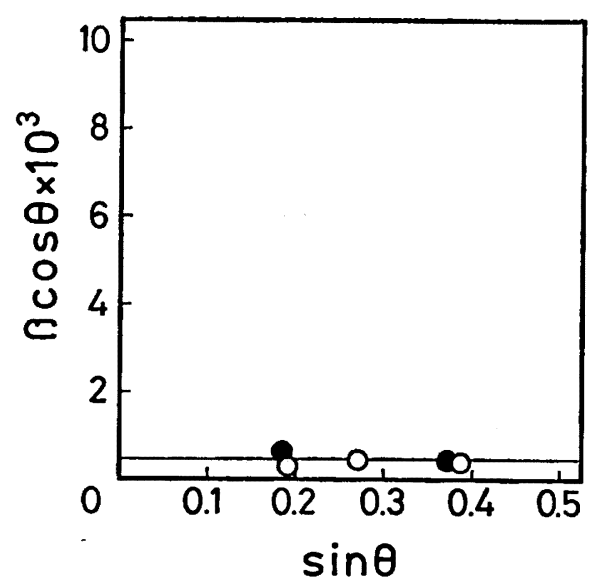

Fig. 9 Plots of $\beta \cos \theta$ vs. $\sin \theta$ for $\mathrm{Pb}\left(\mathrm{Zr}_{0.8} \mathrm{Ti}_{0.7}\right) \mathrm{O}_{3}$ prepared by COMBINATION method

Firing conditions : $1100^{\circ} \mathrm{C}, 1 \mathrm{~h}$

$\bigcirc:$ For $h k 0$ diffraction,

: For $00 l$ diffraction

12）高橋則夫，掛川一幸，富澤俊昭，佐々木義典，日化，投稿中 
A)

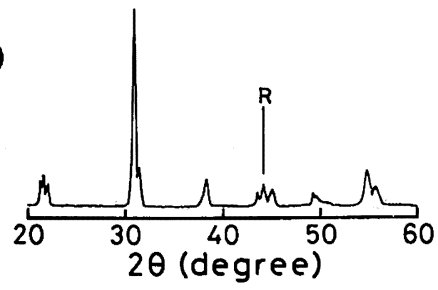

B)

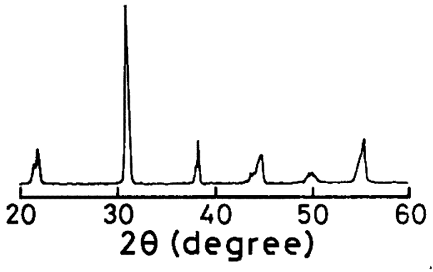

C)

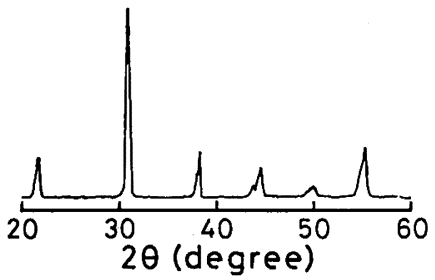

Fig. 10 XRD patterns of $\mathrm{Pb}\left(\mathrm{Zr}_{0.53} \mathrm{Ti}_{0.47}\right) \mathrm{O}_{3}$ prepared by A) DRY method, B) COMBINATION method, C) FULL method

$R$ : Peak of rhombohedral phase

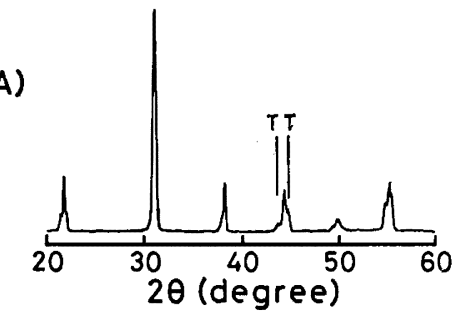

B)

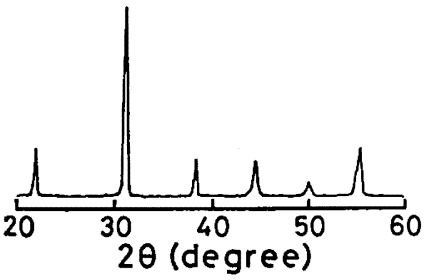

C)

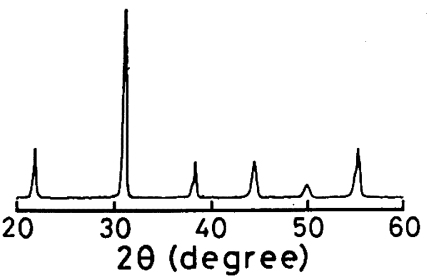

Fig. 11 XRD patterns of $\mathrm{Pb}\left(\mathrm{Zr}_{0.54} \mathrm{Ti}_{0.46}\right) \mathrm{O}_{3}$ prepared by A) DRY method, B) COMBINATION method, C) FULL method

$\mathrm{T}$ : Peak of tetragonal phase
配はみられず，この方法による誤差の範囲内では組成変動は認め られない。

組成変動のない PZT は正方晶と三方晶の相境界 (MPB) 付 近でも，その組成によって決まる正方晶か三方晶の単一相とな る。組成変動がある場合, 相境界付近の組成の PZT は正方晶と 三方晶が混在する状態となる ${ }^{19)}$ 。このため相境界付近の組成の $\mathrm{X}$ 線回折パターンを調べることにより微少の組成变動を検知するこ とができる。組み合わせ法拉よび全倲結乾燥法により合成された PZT は $\beta \cos \theta \sim \sin \theta$ プロットによる方法で組成変動を検知で きなかったので，相境界付近の組成の X線回折パターンにより検 討した。

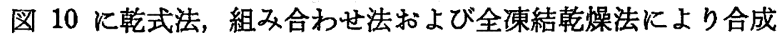
された $\mathrm{Pb}\left(\mathrm{Zr}_{0.53} \mathrm{Ti}_{0.47}\right) \mathrm{O}_{3}$ のX線回折パターンを示す。この組成 は正方晶領域に属するが組成变動があると三方晶のピークが現わ れる。乾式法により合成された PZT（図 $10(\mathrm{~A})$ ) には三方晶の ピークが現われている。組み合わせ法打よび全凍結乾燥法による PZT (四 $10(B)(C))$ 性正方晶の単一相であることから組成变 動がないことがわかる。

図 11 K $\mathrm{Pb}\left(\mathrm{Zr}_{0.54} \mathrm{Ti}_{0.46}\right) \mathrm{O}_{3}$ のX線回折パターンを示す。この 組成は三方晶領域に属するが組成変動があると正方晶のピークが 現われる。翰式法により合成された PZT（図 11 (A)) Kは, 正 方晶のピークが現われていることから組成変動があることがわか る。この組成についても組み合わせ法扰よび全涷結乾燥法による PZT (図 11 (B) (C)) は三方晶の単一相であることから組成変 動がないことがわかる。

図 12 に $700^{\circ} \mathrm{C}$ から $1000^{\circ} \mathrm{C}$ の間で 1 時間か焼した後, $1100^{\circ} \mathrm{C}$ で1 時間燒結させて得られた PZT のかさ密度を示す。組み合わ せ法および全凍結乾燥法による PZT はすべてのか烧温度につい て斡式法による PZT より密度が大きかった。また，乾式法での 最大㛙結密度は $6.1 \mathrm{~g} / \mathrm{cm}^{3}$, 組み合わせ法では $7.47 \mathrm{~g} / \mathrm{cm}^{3}$, 全凍 結乾燥法では $7.45 \mathrm{~g} / \mathrm{cm}^{3}$ であった。このことから，涷結乾燥法

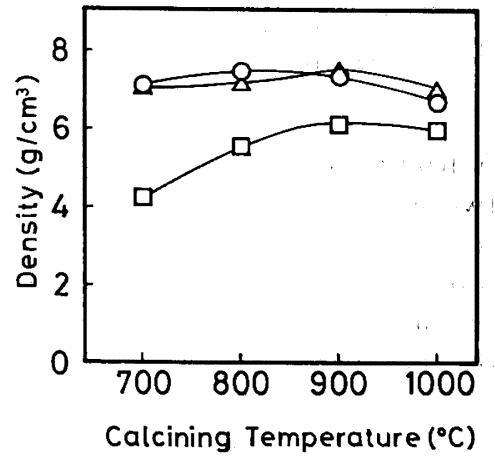

Fig. 12 Relations between bulk density and calcining temperature

Sintering conditions : $1100^{\circ} \mathrm{C}, 1 \mathrm{~h}$

$\square$ : DRY method,

$\triangle$ : COMBINATION method,

$O:$ FULL method

13) K. Kakegawa, J. Mohri, K. Takahashi, S. Shirasaki, Solid State Commun., 24, 769(1977). 


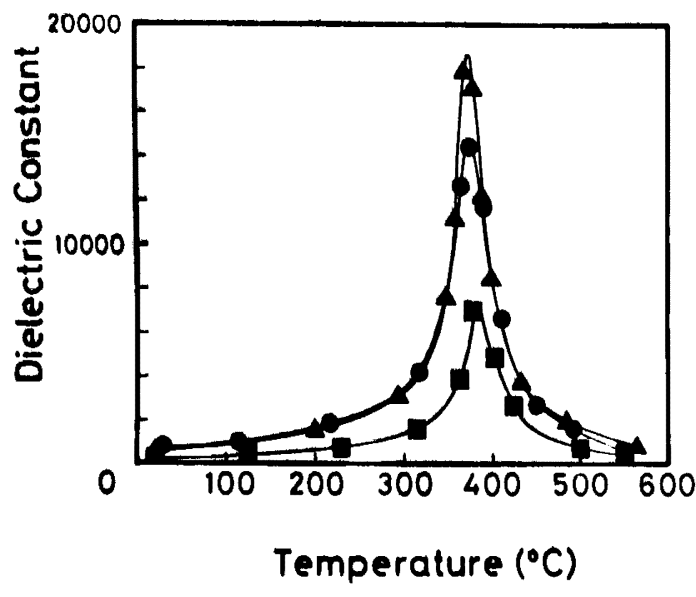

Fig. 13 Dielectric constant of $\mathrm{Pb}\left(\mathrm{Zr}_{0.84} \mathrm{Ti}_{0.40}\right) \mathrm{O}_{3}$ as a function of temperature

: DRY method,

$\triangle$ : COMBINATION method,

: FULL method

により得られた䉼体の烧綃吽が優れているこよがれか，た。 因 13 に各方法により介成された $\mathrm{Pb}\left(\mathrm{Zr}_{0.84}, \mathrm{Tl}_{0.48}\right) \mathrm{O}_{8}$ の锈電事

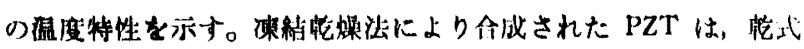

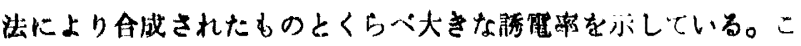

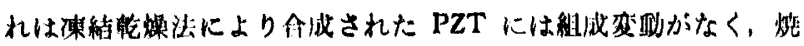
絊牲しよいためと考えられる。

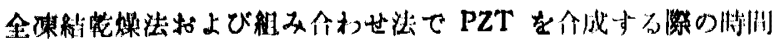
的な效率について接えてみる。組み合わせ治でのチタン、ジルコ

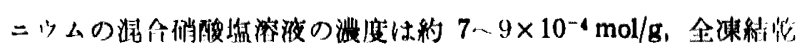

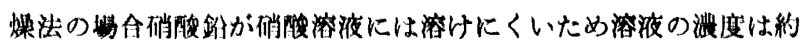

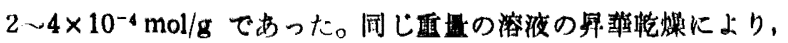
組み合わ世法では全凍結㙂燥法の約 2.5 倍の PZT を跟絡的に得 ることができた。したがって㭙間的な妙嘌の点からは組み合わせ 法の方が有利であることがわかる。

\section{4 結楄}

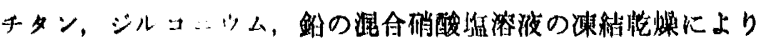

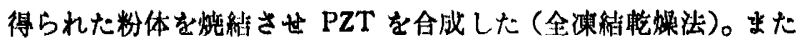

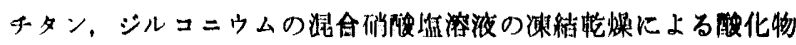
と $\mathrm{PbO}$ との固体間反纫により PZT を合成した（組み合わせ 法。そしてこれらの方法特よび，従来法である聠式法による

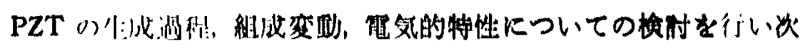
の結諭を德た。

1) 叔式法では中归生成物として $\mathrm{PbTiO}_{8}$ が生した。組み合わ

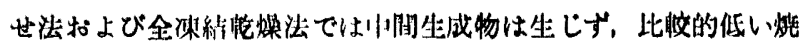
成温度で PZT が娍した。このことから組み合わせ法呿よび全 凍結䭂煤法により得られた粉体の反仙侳は良好であることがわか つた。

2）喼式法に上り得られた PZT には大きな組成変㽖があっ

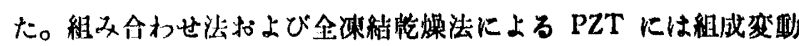

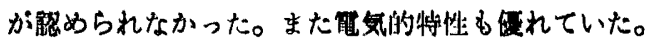

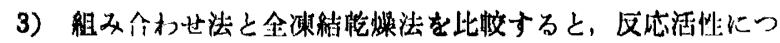
いては全涷結轮煤法の方が多少優れてていた。PZT を合成する際 の時間的な效率に関しては組み合わせ法の方が有利である。

\title{
Synthesis of $\mathrm{Pb}\left(\mathrm{Zr}_{x} \mathrm{Ti}_{1-x}\right) \mathrm{O}_{3}$ by Freeze Drying Method
}

\author{
Satoshi Kondou**, Kazuyuki Kakegawa* and Yoshinori Sasakı \\ Faculty of lingineering, ('hilha University; Yayoi-Cho, (hilha-shi 260 Japan \\ ** Present address: TOSOH ('oporation; Hayakawa Ay'use-shi 252 Japan
}

A lead zirconate titanate (PZT) was prepared by following methods : 1) Solid-solid reaction between $\mathrm{TiO}_{2}, \mathrm{ZrO}_{2}$ and $\mathrm{PbO}$ (DRY method), 2) solid-solid reaction between $\mathrm{PbO}$ and a mixed oxide prepared by a freeze drying of a mixed solution of titanium nitrate and zirconium nitrate (COMBINATION method), 3) freeze drying of a mixed solution of titanium nitrate, zirconium nitrate and lead nitrate (FULL method).

By the DRY method, $\mathrm{PbTiO}_{3}$ was formed as an intermediate product and a single phase PZT was obtained by a firing at $1100^{\circ} \mathrm{C}$. By the COMBINATION method, the single phase PZT was obtained by a firing at $900^{\circ} \mathrm{C}$ without the formation of the intermediate product. By the FULL method, the single phase PZT was obtained by a firing at $580^{\circ} \mathrm{C}$ without the formation of the intermediate product. A compositional fuctuation of P'T prepared by the COMBINATION method and that by the FULL method were not detected by X-ray diffraction analysis. The sinterability of PZT prepared by the COMBINATION method and that by the FULL method were higher than that by the DRY method. The permittivity peak of PZT prepared by the COMBINATION method and that by the IUULI, method at the Curie temperature were about twice as large as that by the DRY method. 